\title{
SHIELDING PROPERTIES OF ALLOY 709 ADVANCED AUSTENITIC STAINLESS STEEL AS CANDIDATE CANISTER MATERIAL IN SPENT FUEL DRY CASKS
}

\author{
ZEINAB Y. ALSMADI*, MOHAMED BOURHAM
}

Department of Nuclear Engineering, North Carolina State University,Raleigh, NC 27695-7909, USA

\section{ABSTRACT}

Shielding properties of Alloy 709 are computationally investigated in this work as a candidate material for the inner canister in multi-layered spent fuel dry cask. The concept of the cask canister in this work consists of an inner canister made of Alloy 709, intermediate shielding coating of specialty glass containing metal oxides of $0.8 \mathrm{PbO} / 0.1 \mathrm{Al}_{2} \mathrm{O}_{3} / \mathrm{O}_{0} \mathrm{SiO}_{2}$ all by weight percent and is denoted as Glass 6, and an outer shielding layer of synthesized concrete containing ferrophosphorus $\mathrm{Fe}_{3} \mathrm{P} /$ magnetite and $\mathrm{Fe}_{3} \mathrm{O}_{4} /$ lead oxide $\mathrm{PbO}$ and is denoted as Concrete 6. Alloy 709 proved to have the highest attenuation among other steels which can be ascribed to the high weight fraction of Chromium (Cr) and Nickel (Ni) and the additives of Titanium (Ti), Niobium (Nb) and Boron (B) that play a role in enhancing the attenuation behavior of the alloy against gamma-rays among other stainless steels. Alloy 709 provides the greatest reduction in exposure rate, exposure buildup factor and half-value layer (HVL) and minimum mean free path (MFP) values at different photon energies, which explains its better attenuation among other steels and thus its enhanced shielding effectiveness as candidate canister material in dry storage casks of spent fuel.

KEYWORDS: Gamma-rays shielding, Spent fuel dry cask, Alloy 709, Attenuation Coefficients, Exposure rate

Received: Oct 22, 2020; Accepted: Nov 12, 2020; Published: Dec 18, 2020; Paper Id.: IJPRDEC20202

\section{INTRODUCTION}

Exposure to ionizing radiation such as gamma-rays can affect individuals working in facilities in nuclear energy production fields, nuclear waste storage sites, radioactive sources in the medical and industry applications. This kind of exposure is harmful to human beings and can cause diseases like cancer and even death [1]. Due to the overwhelming concerns on the effect of radiation exposure on humans and the surrounding environments, new shielding materials have to be continuously developed with effective radiation shielding properties in order to reduce the intensity of external radiation to a lower, protected level. In the past decades, many efforts have been made by researchers to design and develop new shielding materials and to evaluate and characterize their shielding properties using experimental and computational calculation methods [2-9].

As spent fuel pools reach their capacity limit of stored fuel assemblies in nuclear power plants, the fuel assemblies are removed and stored in pool storage to cool down, and then they are placed in dry casks storage systems in which they emit high-levels of radiation. Therefore, dry casks should provide complete shielding, safety, heat removal and physical protection. Dry casks are designed with an inner layer of stainless steel as the spent fuel storage canister, and the canister may be coated with a thin layer of glass then surrounded with a concrete overpack [10]. The most common shielding materials that have been investigated for radiation shielding purposes in nuclear reactors and spent fuel storage are concrete $[6,10,11]$ and glass-oxide materials $[2-10,12,13]$. Concrete is inexpensive shielding material and is widely used in nuclear facilities such as nuclear reactors, hot cells and high- 
level waste dry casks. It is proven to have high values of linear and mass attenuation coefficients for gamma rays and neutrons and high compressive, low tensile strength and low thermal conductivity $[2,11]$. Additionally, it is an easy process of preparing the concrete from the cement, such as Portland, and mixing it with additives and aggregates containing elements with good shielding properties then casting it into various shapes [11, 14, 15]. On the other hand, glass-based materials are widely used in nuclear and medical applications, laser facilities and solar cells since they have a lot of interesting mechanical and physical properties that make them attractive such as corrosion resistance, hardness, transparency to visible light and ease of production $[2,6,16]$. Furthermore, glasses contain heavy metal oxides providing good thermal stability and other transition metal oxides that contribute in increasing the density $[6,17,18]$. Dry cask inner canisters are composed of austenitic stainless steels in which they are widely used in nuclear engineering applications due to their corrosion-resistance, high-temperature strength, and economic feasibility. They are primarily composed of $\mathrm{Fe}-\mathrm{Cr}$ $\mathrm{Ni}$ alloys with face-centered-cubic (FCC) crystal structures to reduce the diffusivity in the lattice [19]. Conventional and advanced austenitic stainless steels are alloyed with various elements to improve their mechanical properties at different temperatures. For example, chromium $(\mathrm{Cr})$ is added to improve hardenability, wear resistance, strength and corrosion resistance while nickel $(\mathrm{Ni})$ is added to stabilize the austenite, increase the corrosion resistance and play a role in solid solution strengthening [19-21]. An advanced austenitic stainless steel known as Alloy 709 (Fe-25Ni-20Cr) is developed by Nippon Steel (Tokyo, Japan) for boiler tubing and high-temperature applications such as ultra-supercritical (USC) power plants and Sodium-cooled Fast Reactors (SFRs). The outstanding mechanical properties of Alloy 709 allow the opportunity to utilize it as a structural material in some of the reactor components including the reactor cladding, pressure vessels and gas turbines in Generation-IV (Gen-IV) nuclear reactors such as SFR, which is being designed to operate at high temperatures, high corrosive environments and high radiation doses [19, 22]. While there are many studies conducted to study the properties of different shielding materials used in spent fuel dry casks such as glasses [2-10,12,13], concrete [6, $10,11]$ and stress corrosion cracking (ESCC) of conventional stainless steels canisters [23, 24], no studies were conducted on the Alloy 709 advanced austenitic stainless steel as a new candidate canister material in dry storage casks of spent fuel.

In this paper, the shielding properties of Alloy 709 are investigated as an inner canister material in multi-layered spent fuel dry cask using computational simulation. The concept of the cask canister consists of three layers: the inner spent fuel package canister made of Alloy 709 advanced austenitic stainless steel which is studied here, an intermediate shielding coating of specialty high-density glass denoted as 'Glass 6 ' from the work of Waly et al. [10, 13], and an outer shielding layer of concrete overpack denoted as 'Concrete 6' from the work of Waly et al. [10, 11].

\section{MATERIALS AND METHODS}

\subsection{Materials}

The material investigated in this work is Fe-25Ni-20 Cr advanced austenitic stainless steel known as Alloy 709 , that is stabilized by nitrogen and strengthened by niobium with the chemical composition and density shown in Table 1 [19, 22]. Other stainless steels are used in this study for the purpose of comparison with Alloy 709 such as 303Cu stainless steel, AISI 304 stainless steel and Type 316 stainless steel with the chemical compositions shown in Table 1 [25, 26]. Alloy 709 has adequate mechanical properties compared to other steels such as corrosion-resistance, high strength, sodium compatibility, thermal stability and good creep and creep-fatigue properties [19, 22, 27]. Table 2 shows some of the mechanical properties of Alloy 709 compared to other stainless steels at room temperature and high temperatures, since the temperature range inside the dry cask stainless steels vary from near ambient up to $400^{\circ} \mathrm{C}\left(752^{\circ} \mathrm{F}\right)$ [28-33]. On the other 
hand, the intermediate shielding coating of lead oxide glass $(\mathrm{PbO})$ is getting a lot of attention in radiation shielding due to their transparency to visible light, high density and high thermal stability in which it helps reducing the thermal loading and prevent the accumulation of thermal stresses and cracking due to radiation absorption [10,34]. According to Waly et al. [13], Glass 6 is proven to have a high mass attenuation coefficient and a small half value layer (HVL) with the chemical composition and density given in Table 3. The outer shielding layer of concrete overpack is a very popular structural and shielding material which is attributed to the additives and aggregates added to it with high atomic number and high density and thus, contribute in improving its shielding effectiveness [10,14]. Waly et al [11] have studied the gamma-ray shielding of concrete materials with different additives in comparison to ordinary concrete, in order to decrease the overpack thickness and increase the density and thus, prevent any difficulties associated with storage costs, transportation and loading. They have concluded that blended 'Concrete 6' with the chemical composition and density shown in Table 4, has about 9 orders of magnitude of exposure rate less than that of ordinary concrete.

The source of the spent fuel used in this work is the H. B. Robinson spent fuel that was depleted according to 72 GWd/MTU burnup followed by an 8-year decay. The isotopic composition of the spent fuel can be found in Waly, et al. [11] and Naegeli [35].

Table 1: Chemical composition (wt\%) and density of Alloy 709 and other stainless steels [19, 22, 25, 26]

\begin{tabular}{|c|c|c|c|c|c|c|c|c|c|c|c|c|c|c|c|}
\hline Material & $\begin{array}{c}\text { Density } \\
\text { (g/cc) }\end{array}$ & C & $\mathrm{Mn}$ & Si & $\mathbf{P}$ & $S$ & $\mathrm{Cr}$ & $\mathrm{Ni}$ & Mo & $\mathbf{N}$ & $\mathrm{Ti}$ & Nb & B & $\mathrm{Cu}$ & $\mathrm{Fe}$ \\
\hline Alloy 709 & 7.85 & 0.07 & 0.91 & 0.44 & 0.014 & 0.001 & 19.93 & $\begin{array}{c}24.9 \\
8\end{array}$ & 1.51 & $\begin{array}{c}0.14 \\
8\end{array}$ & 0.04 & 0.26 & $\begin{array}{c}0.00 \\
45\end{array}$ & - & Bal. \\
\hline $303 C u$ SS & 7.9 & $\begin{array}{c}0.06 \\
1\end{array}$ & 1.48 & 0.68 & - & - & 17.4 & 6.6 & $\begin{array}{c}0.03 \\
2\end{array}$ & $\begin{array}{c}0.02 \\
9\end{array}$ & - & - & - & 1.79 & Bal. \\
\hline $\begin{array}{c}\text { AISI } 304 \\
\text { SS }\end{array}$ & 7.85 & $\begin{array}{c}0.06 \\
0\end{array}$ & 1.31 & 0.39 & - & - & 18.1 & 8.0 & $\begin{array}{c}0.04 \\
0\end{array}$ & $\begin{array}{c}0.03 \\
3\end{array}$ & - & - & - & 0.07 & Bal. \\
\hline $\begin{array}{c}\text { Type } 316 \\
\text { SS }\end{array}$ & 7.87 & 0.08 & 2.0 & 0.75 & 0.045 & 0.03 & 17.0 & 12.0 & 2.5 & 0.10 & - & - & - & - & Bal. \\
\hline
\end{tabular}

Table 2: Mechanical properties of Alloy 709 and other stainless steels at different temperatures [29-33].

\begin{tabular}{|c|c|c|c|c|c|c|c|c|}
\hline Material & \multicolumn{2}{|c|}{$\begin{array}{l}\text { Ultimate Tensile } \\
\text { Strength (MPa) }\end{array}$} & \multicolumn{2}{|c|}{$\begin{array}{l}\text { Yield Strength } \\
(\mathrm{MPa})\end{array}$} & \multicolumn{2}{|c|}{ Ductility (\%) } & \multicolumn{2}{|c|}{$\begin{array}{l}\text { Young's Modulus } \\
\text { (GPa) }\end{array}$} \\
\hline \multirow[t]{3}{*}{ Alloy 709} & RT & \multirow{3}{*}{$\begin{array}{c}\mathbf{6 0 0}^{\circ} \mathbf{C} \\
594\end{array}$} & RT & 600 & RT & 600 & RT & $600^{\circ} \mathrm{C}$ \\
\hline & \multirow{2}{*}{640} & & & ${ }^{\mathbf{O}} \mathbf{C}$ & & & \multirow{2}{*}{193} & \multirow{2}{*}{156} \\
\hline & & & 270 & 227 & 30 & 44 & & \\
\hline \multirow{2}{*}{ 303Cu SS } & \multirow{2}{*}{\multicolumn{2}{|c|}{\begin{tabular}{|l|} 
RT \\
231
\end{tabular}}} & \multirow{2}{*}{\multicolumn{2}{|c|}{$\begin{array}{l}\text { RT } \\
154\end{array}$}} & \multirow{2}{*}{\multicolumn{2}{|c|}{\begin{tabular}{|l} 
RT \\
56 \\
\end{tabular}}} & \multirow{2}{*}{\multicolumn{2}{|c|}{\begin{tabular}{|l|} 
RT \\
124 \\
\end{tabular}}} \\
\hline & & & & & & & & \\
\hline \multirow[t]{2}{*}{ AISI 304 SS } & \multicolumn{2}{|c|}{$\begin{array}{ll}\text { RT } & 482 \\
& { }^{\circ} \mathrm{C}\end{array}$} & \multicolumn{2}{|l|}{ RT } & \multicolumn{2}{|l|}{ RT } & \multicolumn{2}{|c|}{$\begin{array}{ll}\text { RT } & 482 \\
& { }^{\circ} \mathrm{C}\end{array}$} \\
\hline & 579 & 414 & 290 & 125 & 55 & 36 & 193 & 160 \\
\hline \multirow[t]{3}{*}{ Type 316 SS } & \multirow{3}{*}{$\begin{array}{l}\text { RT } \\
579\end{array}$} & \multirow{3}{*}{$\begin{array}{c}482^{\circ} \mathrm{C} \\
484\end{array}$} & \multirow[t]{2}{*}{ RT } & \multirow{2}{*}{$\begin{array}{l}482 \\
{ }^{\circ} \mathrm{C}\end{array}$} & RT & $482^{\circ} \mathrm{C}$ & \multirow[t]{2}{*}{ RT } & \multirow{2}{*}{$\begin{array}{l}482 \\
{ }^{4}{ }^{\circ} \mathrm{C}\end{array}$} \\
\hline & & & & & 50 & 47 & & \\
\hline & & & 290 & 148 & & & 193 & 162 \\
\hline
\end{tabular}


Table 3: Chemical composition (wt\%) and density of Glass 6 [10, 13].

\begin{tabular}{|l|l|l|l|l|}
\hline Material & \multicolumn{1}{|c|}{ Density $(\mathrm{g} / \mathrm{cc})$} & $\mathrm{PbO}$ & $\mathrm{Al}_{2} \mathrm{O}_{\mathbf{3}}$ & $\mathrm{SiO}_{\mathbf{2}}$ \\
\hline Glass 6 & 8.284 & 80 & 10 & 10 \\
\hline
\end{tabular}

Table 4: Chemical composition (wt\%) and density of Concrete $6[10,11]$

\begin{tabular}{|l|l|l|l|l|l|l|l|l|l|l|l|l|l|}
\hline Material & $\begin{array}{l}\text { Density } \\
\text { (g/cc) }\end{array}$ & $\mathrm{CaO}$ & $\mathrm{SiO2}$ & $\mathrm{Al2O3}$ & $\mathrm{Fe2O3}$ & $\mathrm{MgO}$ & $\mathrm{SO3}$ & $\mathrm{Na2O}$ & $\mathrm{K2O}$ & $\mathrm{H} 2 \mathrm{O}$ & $\mathrm{CaCO3}$ & $\mathrm{Fe3O4}$ & $\mathrm{PbO}$ \\
\hline $\begin{array}{l}\text { Concrete } \\
\mathbf{6}\end{array}$ & 4.64 & 8.8074 & 21.8892 & 0.4194 & 0.699 & 0.4194 & 0.4194 & 0.04194 & 0.09786 & 7.63 & 4.7034 & 39.195 & 15.678 \\
\hline
\end{tabular}

\subsection{Computational Methods}

MicroShield $^{\circledR}$ v9.05 (MSD9) software package [36] is the computational tool used in this study to calculate the attenuation coefficients of stainless steels canister materials and perform shielding assessment based on the materials composition and density. MicroShield ${ }^{\circledR}$ is a deterministic code used as a comprehensive dose and shielding assessment program in many shielding applications in industry and approved by the US Nuclear regulatory Commission (NRC) to design shields and estimate their exposure to gamma radiation as in several shielding studies [37, 38]. In this work, the design of the multilayered spent fuel dry cask is modeled as a cylindrical source of spent fuel surrounded by three cylindrical layers as shown in Figure. 1. The source dimensions are $8.727 \mathrm{ft}$ radius and $20 \mathrm{ft}$ height while the inner stainless steel layer is $0.27 \mathrm{ft}$ thick followed by $0.2 \mathrm{ft}$ thick of an intermediate shielding coating of Glass 6 , then $1.8 \mathrm{ft}$ thick of an outer shielding layer of Concrete 6 . An air gap of $0.167 \mathrm{ft}$ between the canister and the concrete is added for heat removal and venting. The dose is measured half-way up at the outer surface of the cask. As shown in Figure. 1, inputs to MicroShield ${ }^{\circledR}$ includes the dry cask geometry with source and shields dimensions, source and shields density, and the spent fuel isotopic composition.

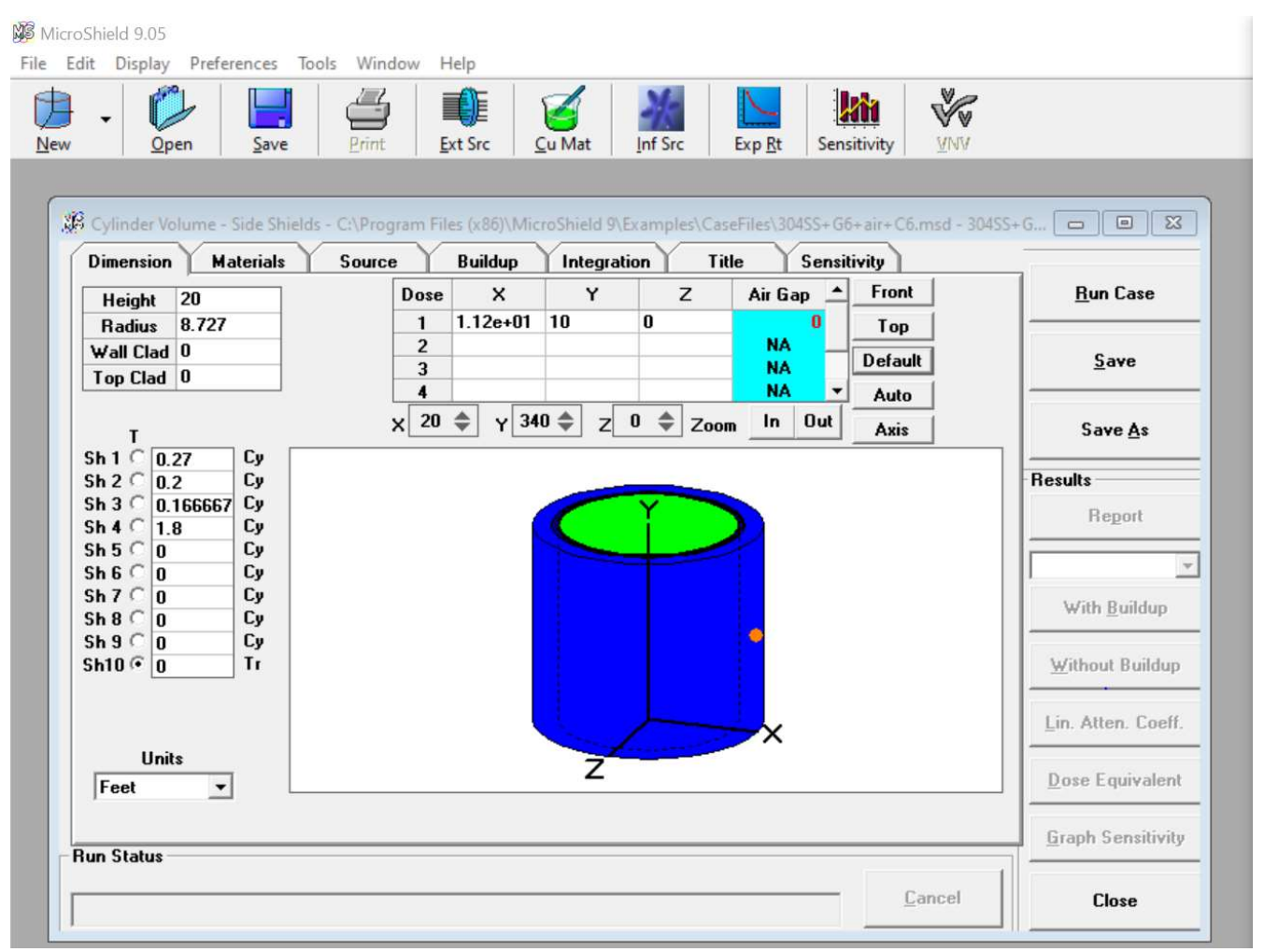




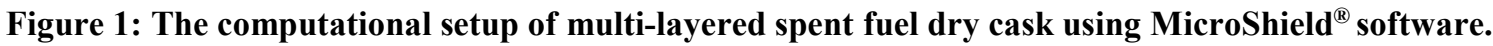

\section{RESULTS AND DISCUSSIONS}

\subsection{Attenuation Coefficients}

When gamma radiation of intensity $I_{o}$ interacts with a target material of thickness $x$, it can undergo three types of interactions: The Photoelectric Effect, Compton Scattering and Pair Production and thus, the transmitted intensity by the target material is given as following [13]:

$I=I_{o} e^{-\mu x}$

where $I_{o}$ is the incident intensity before shielding, $I$ is the transmitted intensity after shielding, $\mu$ is the linear attenuation coefficient $\left(\mathrm{cm}^{-1}\right)$ and $x$ is the physical thickness of the material. The linear attenuation coefficient is defined as the interaction probability of photon with the target material per unit path length, and can be written as following [11]:

$\mu_{i}=N_{i} \sigma_{i}$

where $\mu_{i}$ is the total linear attenuation coefficient, $N_{i}$ is the number of atoms per $\mathrm{cm}^{3}$ and $\sigma_{i}$ is the microscopic cross section $\left(\mathrm{cm}^{2}\right)$. However, $N_{i}$ depends on the density of the material, which in turn varies with the physical state of the material, and therefore another parameter that describes the gamma-rays attenuation is known as the mass attenuation coefficient $(\mu / \rho)$, which is defined as the interaction probability of photon with the target material per unit mass, and it is expressed as follow $[2,13]$ :

$\mu_{i} / \rho_{i}=\ln \left(I / I_{o}\right) / \rho x$

where $\mu_{i} / \rho_{i}$ is the mass attenuation coefficient $\left(\mathrm{cm}^{2} / \mathrm{g}\right)$ and $\rho_{i}$ is the density $\left(\mathrm{g} / \mathrm{cm}^{3}\right)$. The mass attenuation coefficient for a mixture of materials is given as [13]:

$(\boldsymbol{\mu} / \rho)_{\text {total }}=\sum_{i} w_{i}(\mu / \rho)_{i}$

where the total mass attenuation coefficient, $(\mu / \rho)_{\text {total }}$ is the sum of the mass attenuation coefficient of each material, $(\mu / \rho)_{i}$ multiplied by the weight fraction, $w_{i}$ of component $i$. The linear and mass attenuation coefficients are very important in radiation shielding assessment since they both describe the materials behavior towards gamma radiation. Figure. 2 shows the linear attenuation coefficient as a function of photon energy for different stainless steels while Figure. 3 shows the mass attenuation coefficient. As shown, Alloy 709 have higher attenuation among other steels at photon energies varying from $0.015 \mathrm{MeV}$ to $0.2 \mathrm{MeV}$ while it is somehow similar in attenuation to other steels at higher energies. At low energies, it can be seen that Alloy 709 and Type 316 SS have close values of attenuation coefficients compared to other steels. At all energies, AISI 304 SS has the lowest gamma-rays attenuation while 303Cu SS exhibited a better attenuation than AISI 304 SS. The high attenuation coefficients of Alloy 709 can be ascribed to the high weight fraction of $\mathrm{Cr}(19.93 \%)$ and $\mathrm{Ni}(24.98 \%)$ and the additives of titanium $(\mathrm{Ti})$, niobium $(\mathrm{Nb})$ and boron (B) which play a role in 
enhancing the attenuation behavior of the alloy against gamma-rays among other stainless steels [19-21].

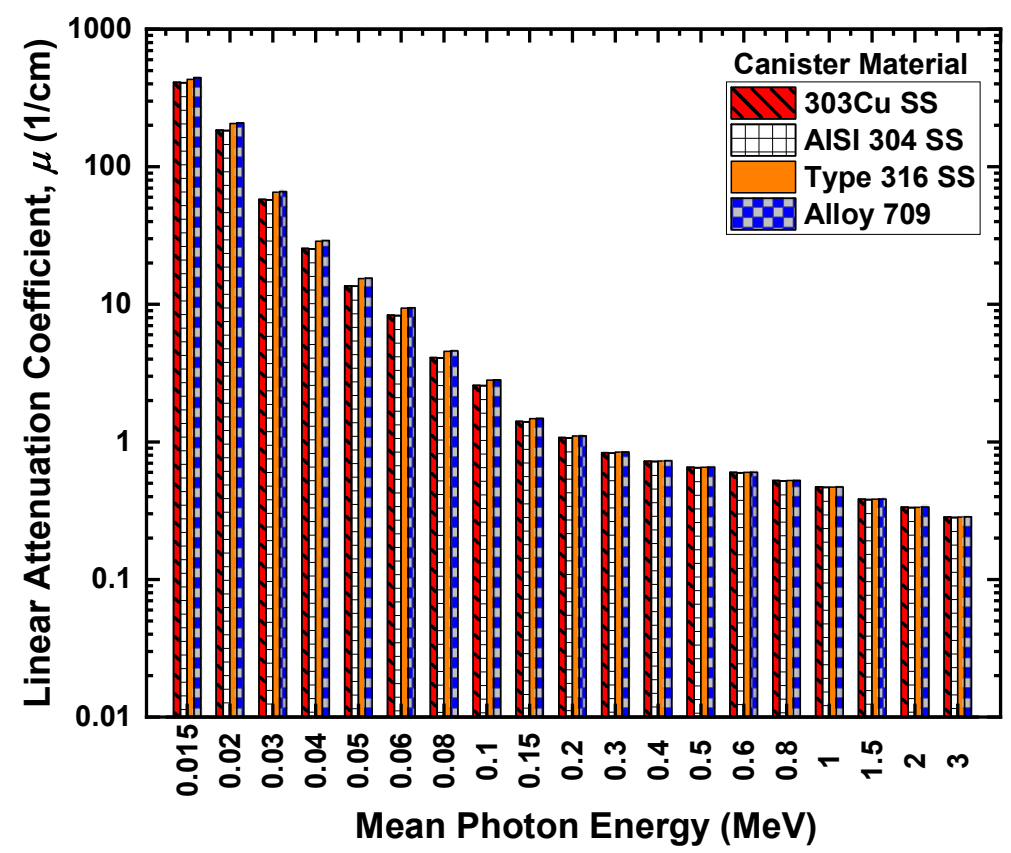

Figure 2: Linear attenuation coefficient vs. photon energy for the selected stainless steels.

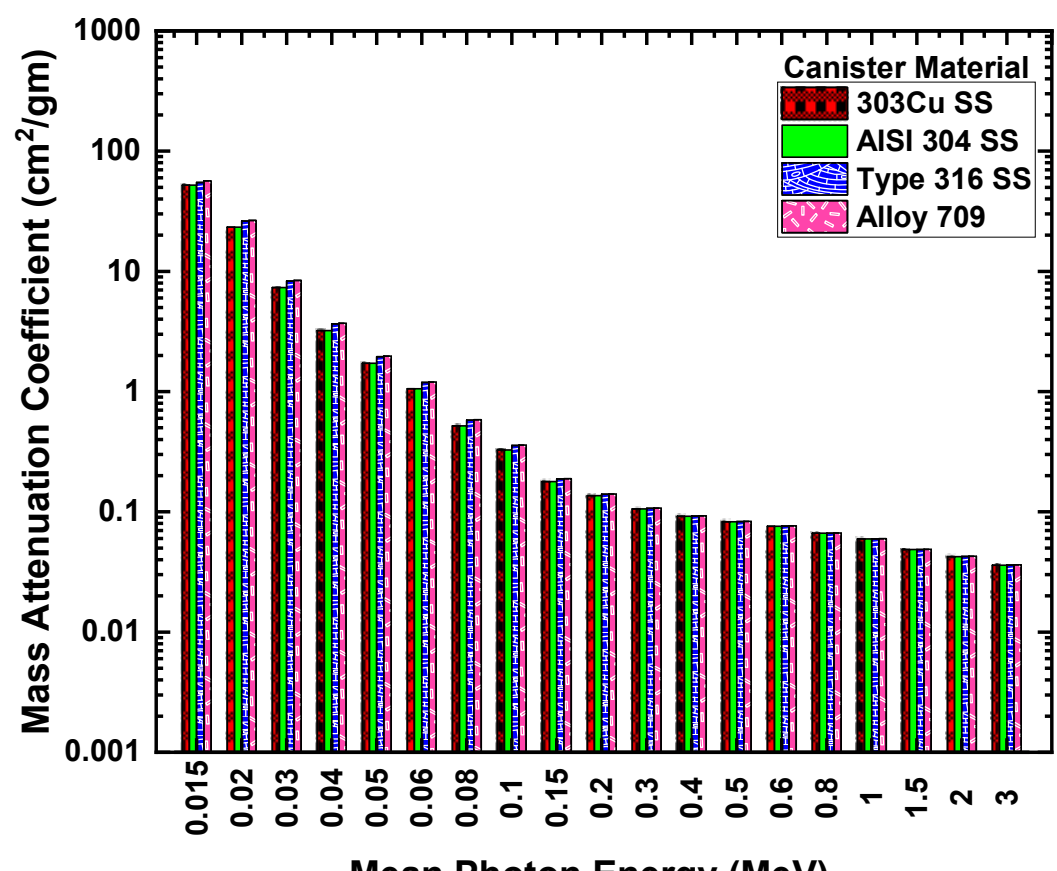

Figure 3: Mass attenuation coefficient vs. photon energy for the selected stainless steels.

\subsection{Exposure Rate}

The exposure rate $(\mathrm{mR} / \mathrm{hr})$ calculated at the outer surface of the cask $10 \mathrm{ft}$ from the bottom (half-way up) is shown in Figure. 4 and Figure. 5 for the selected stainless steels. Figure. 4 shows the exposure rate with no buildup in which the exposure rate at energies below $0.3 \mathrm{MeV}$ is not shown as it is negligible while Figure. 5 shows the exposure rate with buildup. As shown in Figure. 4, the maximum exposure rate occurs for the $1.5 \mathrm{MeV}$ mean photon energy and is about 
1.6E-7 $\mathrm{mR} / \mathrm{hr}$ for all stainless steels. On the other hand, the exposure rate becomes more significant when buildup is included giving a maximum exposure of about $8.08 \mathrm{E}-6 \mathrm{mR} / \mathrm{hr}$ for AISI $304 \mathrm{SS}$ at $1.0 \mathrm{MeV}$ photon energy. Also, buildup is shown to impact the exposure rate at low photon energy groups in which it increases by 23 orders of magnitude at $0.3 \mathrm{MeV}$ gamma-rays for $303 \mathrm{Cu} \mathrm{SS}$. With increasing photon energies, the buildup impact on the exposure rate decreases. Type 316 SS and Alloy 709 have similar exposure rate at energies ranging from $0.015 \mathrm{MeV}$ to $0.4 \mathrm{MeV}$ and they exhibit the minimum exposure rate at energies ranging from $0.02 \mathrm{MeV}$ to $1.0 \mathrm{MeV}$ while AISI 304 SS has the minimum exposure rate at $0.015 \mathrm{MeV}$ photon energy groups and from 1.5 MeV to 4.0MeV (Figure. 5). Alloy 709 provides better reduction in exposure rate at photon energies ranging from $0.5 \mathrm{MeV}$ to $4.0 \mathrm{MeV}$, and the reason for that is linked to its high attenuation coefficients as discussed in the previous section.

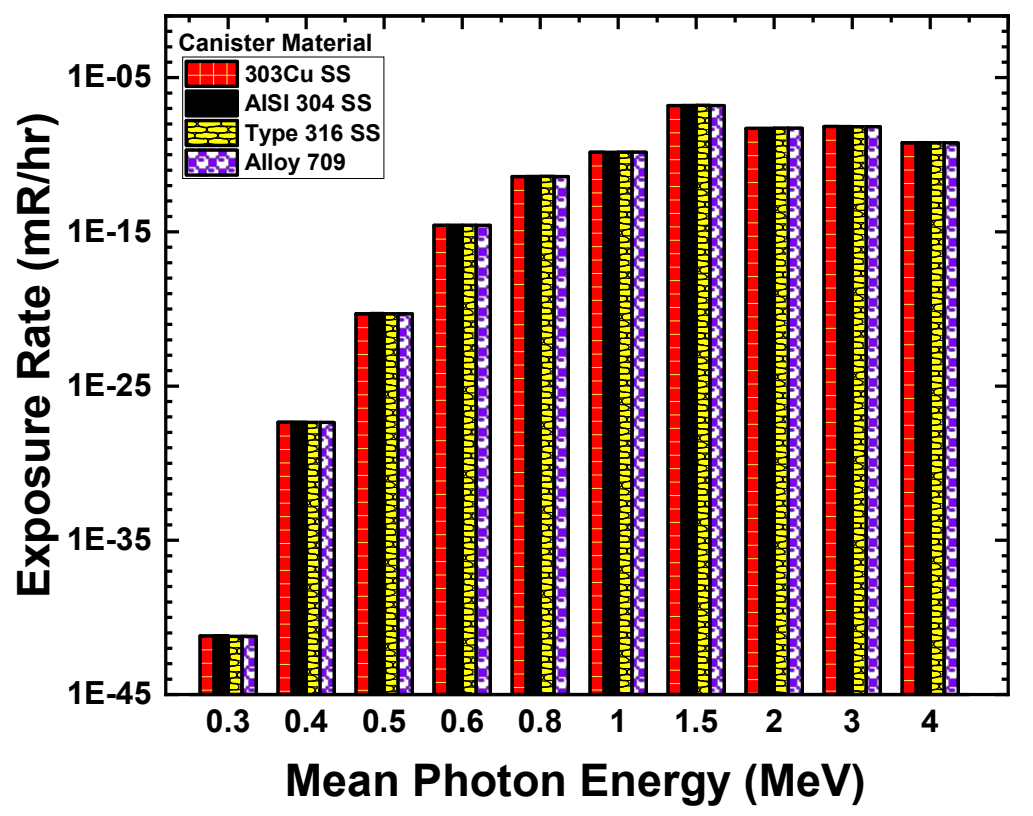

Figure 4: Exposure rate (no buildup) at the outer cask surface for the selected stainless steels.

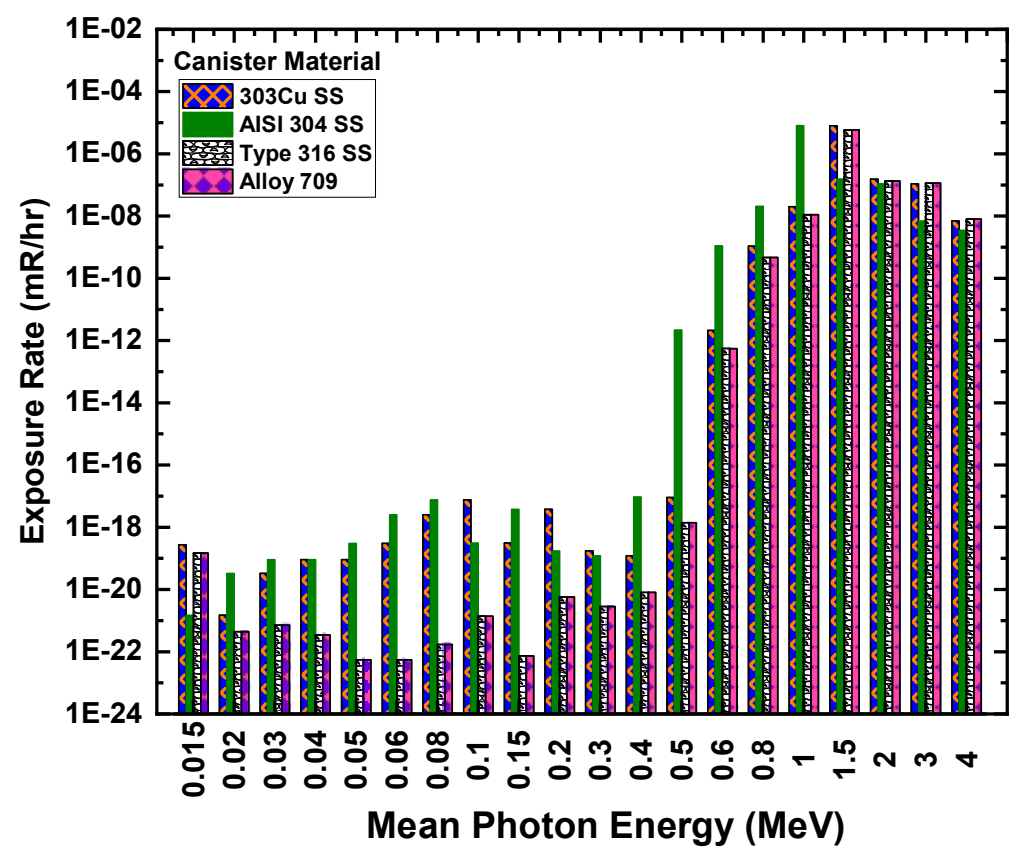


Figure 5: Exposure rate (with buildup) at the outer cask surface for the selected stainless steels.

\subsection{Half Value Layer and Mean Free Path}

Some of the important properties to study in radiation shielding are the half value layer (HVL) and the mean free path (MFP). The MFP is the average distance a gamma ray travels in the target material before interacting and it is the reciprocal of the attenuation coefficient, $1 / \mu$, and has units of length $(\mathrm{cm})$ while the HVL is the thickness of the material at which the intensity of entered radiation is reduced by one half and it is defined as following with units of length (cm) [2]:

$H V L=\frac{\ln (2)}{\mu}$

which indicates that the higher the attenuation, the lower the HVL value and therefore, the better the shielding effectiveness. Figure. 6 shows the HVL values obtained from MicroShield ${ }^{\circledR}$ for the selected stainless steels in which at low energies ranging from $0.015 \mathrm{MeV}$ to $0.2 \mathrm{MeV}$, the HVL can have a minimum value of $0.002 \mathrm{~cm}$ for all stainless steels except for AISI $304 \mathrm{SS}$ and a maximum value of $0.648 \mathrm{~cm}$ for AISI $304 \mathrm{SS}$. Furthermore, at higher energies $(0.3 \mathrm{MeV}-15$ $\mathrm{MeV}$ ), the HVL values increase with increasing photon energy where there is no considerable difference between all stainless steels. The increase in the photon energy leads to higher penetration and thus, greater shield thickness [6]. As shown in Table 5, Alloy 709 exhibits less HVL values at photon energies ranging from $0.06 \mathrm{MeV}$ to $0.5 \mathrm{MeV}$ and from 3.0 $\mathrm{MeV}$ to $15 \mathrm{MeV}$ and therefore, explains its better attenuation among other steels and thus its enhanced shielding properties due to lesser volume requirements to attenuates the same amount of radiation.

On the other hand. Figure. 7 illustrates the incident photon mean free path as function of photon energy. At low energies $(0.015 \mathrm{MeV}-0.2 \mathrm{MeV})$, the MFP depends strongly on the penetrating photon energy while at energies higher than $0.2 \mathrm{MeV}$ and up to $15 \mathrm{MeV}$, the MFP does not show a significant dependence on the photon energy. As shown in Table 6, at photon energies ranging from $0.015 \mathrm{MeV}$ to $0.5 \mathrm{MeV}$ and from $3.0 \mathrm{MeV}$ to $15 \mathrm{MeV}$, Alloy 709 exhibits lower mean free path among other steels and thus can provide better shielding effectiveness as canister material in dry storage casks of spent fuel.

Table 5: Half-value layer (HVL) values at different photon energies for the selected stainless steels

\begin{tabular}{|c|c|c|c|c|}
\hline $\begin{array}{c}\text { Energy } \\
(\mathbf{M e V})\end{array}$ & 303Cu SS & AISI 304 SS & Type 316 SS & Alloy 709 \\
\hline 0.015 & 0.002 & 0.002 & 0.002 & 0.002 \\
\hline 0.02 & 0.004 & 0.004 & 0.003 & 0.003 \\
\hline 0.03 & 0.012 & 0.012 & 0.011 & 0.011 \\
\hline 0.04 & 0.027 & 0.027 & 0.045 & 0.024 \\
\hline 0.05 & 0.051 & 0.051 & 0.074 & 0.073 \\
\hline 0.06 & 0.083 & 0.084 & 0.152 & 0.151 \\
\hline 0.08 & 0.169 & 0.17 & 0.247 & 0.246 \\
\hline 0.1 & 0.269 & 0.27 & 0.47 & 0.468 \\
\hline 0.15 & 0.492 & 0.495 & & \\
\hline
\end{tabular}




\begin{tabular}{|c|c|c|c|c|}
\hline 0.2 & 0.643 & 0.648 & 0.628 & 0.627 \\
\hline 0.3 & 0.829 & 0.834 & 0.823 & 0.822 \\
\hline 0.4 & 0.957 & 0.963 & 0.954 & 1.953 \\
\hline 0.5 & 1.061 & 1.068 & 1.155 & 1.154 \\
\hline 0.6 & 1.154 & 1.162 & 1.324 & 1.323 \\
\hline 0.8 & 1.322 & 1.33 & 1.477 & 1.476 \\
\hline 1.0 & 1.474 & 1.483 & 1.81 & 2.809 \\
\hline 1.5 & 1.806 & 1.817 & 2.071 & 2.433 \\
\hline 2.0 & 2.068 & 2.081 & 2.436 & 2.658 \\
\hline 3.0 & 2.44 & 2.455 & 2.662 & 2.795 \\
\hline 4.0 & 2.675 & 2.692 & 2.801 & 2.875 \\
\hline 5.0 & 2.822 & 2.84 & 2.882 & 2.935 \\
\hline 6.0 & 2.911 & 2.929 & 2.943 & 2.929 \\
\hline 8.0 & 2.985 & 3.004 & 2.939 & 2.831 \\
\hline 10.0 & 2.99 & 3.009 & 2.843 & \\
\hline 15.0 & 2.907 & 2.926 & & \\
\hline
\end{tabular}

Table 6: Mean free path (MFP) values at different photon energies for the selected stainless steels

\begin{tabular}{|c|c|c|c|c|}
\hline $\begin{array}{c}\text { Energy } \\
(\mathrm{MeV})\end{array}$ & 303Cu SS & AISI 304 SS & Type 316 SS & Alloy 709 \\
\hline 0.015 & 0.00243 & 0.00245 & 0.00232 & 0.00225 \\
\hline 0.02 & 0.00542 & 0.00546 & 0.00485 & 0.0048 \\
\hline 0.03 & 0.01725 & 0.01736 & 0.0153 & 0.01515 \\
\hline 0.04 & 0.03928 & 0.03953 & 0.03473 & 0.03444 \\
\hline 0.05 & 0.07342 & 0.07386 & 0.06502 & 0.06452 \\
\hline 0.06 & 0.12002 & 0.12077 & 0.10664 & 0.10589 \\
\hline 0.08 & 0.24378 & 0.24534 & 0.21973 & 0.21848 \\
\hline 0.1 & 0.3876 & 0.39002 & 0.35587 & 0.35423 \\
\hline 0.15 & 0.70972 & 0.71429 & 0.67751 & 0.67568 \\
\hline 0.2 & 0.92851 & 0.93458 & 0.9058 & 0.90416 \\
\hline 0.3 & 1.19632 & 1.20395 & 1.18666 & 1.1854 \\
\hline 0.4 & 1.38007 & 1.3887 & 1.37627 & 1.37495 \\
\hline 0.5 & 1.53092 & 1.54059 & 1.53046 & 1.52929 \\
\hline 0.6 & 1.66528 & 1.67588 & 1.66667 & 1.66528 \\
\hline 0.8 & 1.90694 & 1.91902 & 1.91022 & 1.90876 \\
\hline 1.0 & 2.1263 & 2.13995 & 2.13083 & 2.12947 \\
\hline 1.5 & 2.60485 & 2.62192 & 2.61097 & 2.60892 \\
\hline 2.0 & 2.98329 & 3.0021 & 2.98686 & 2.98418 \\
\hline 3.0 & 3.51989 & 3.54233 & 3.51494 & 3.51 \\
\hline 4.0 & 3.85951 & 3.8835 & 3.84172 & 3.83436 \\
\hline 5.0 & 4.07166 & 4.09668 & 4.0404 & 4.03226 \\
\hline 6.0 & 4.19992 & 4.22654 & 4.158 & 4.14766 \\
\hline
\end{tabular}




\begin{tabular}{|c|c|c|c|c|}
\hline 8.0 & 4.30663 & 4.33463 & 4.24628 & 4.2337 \\
\hline 10.0 & 4.31406 & 4.34028 & 4.23908 & 4.22476 \\
\hline 15.0 & 4.19391 & 4.22062 & 4.10137 & 4.08493 \\
\hline
\end{tabular}

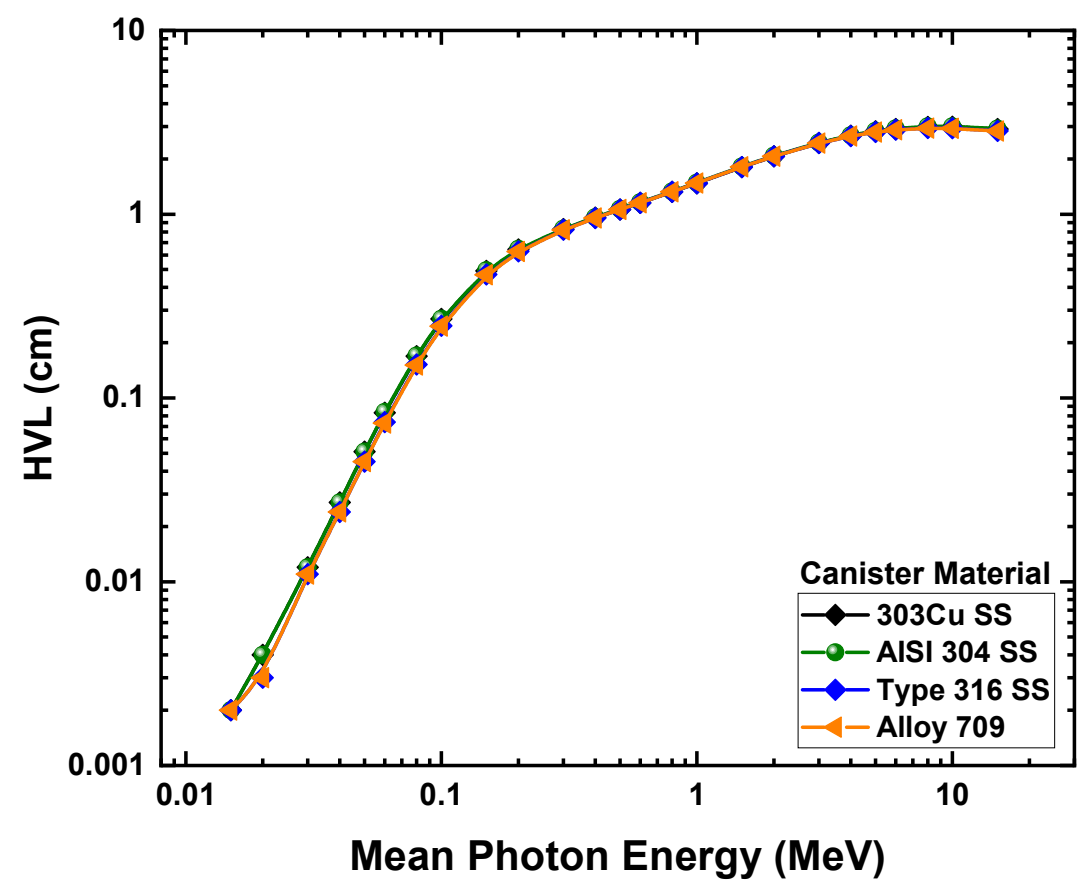

Figure 6: Variation of the half-value layer (HVL) as function of photon energy for the selected stainless steels.

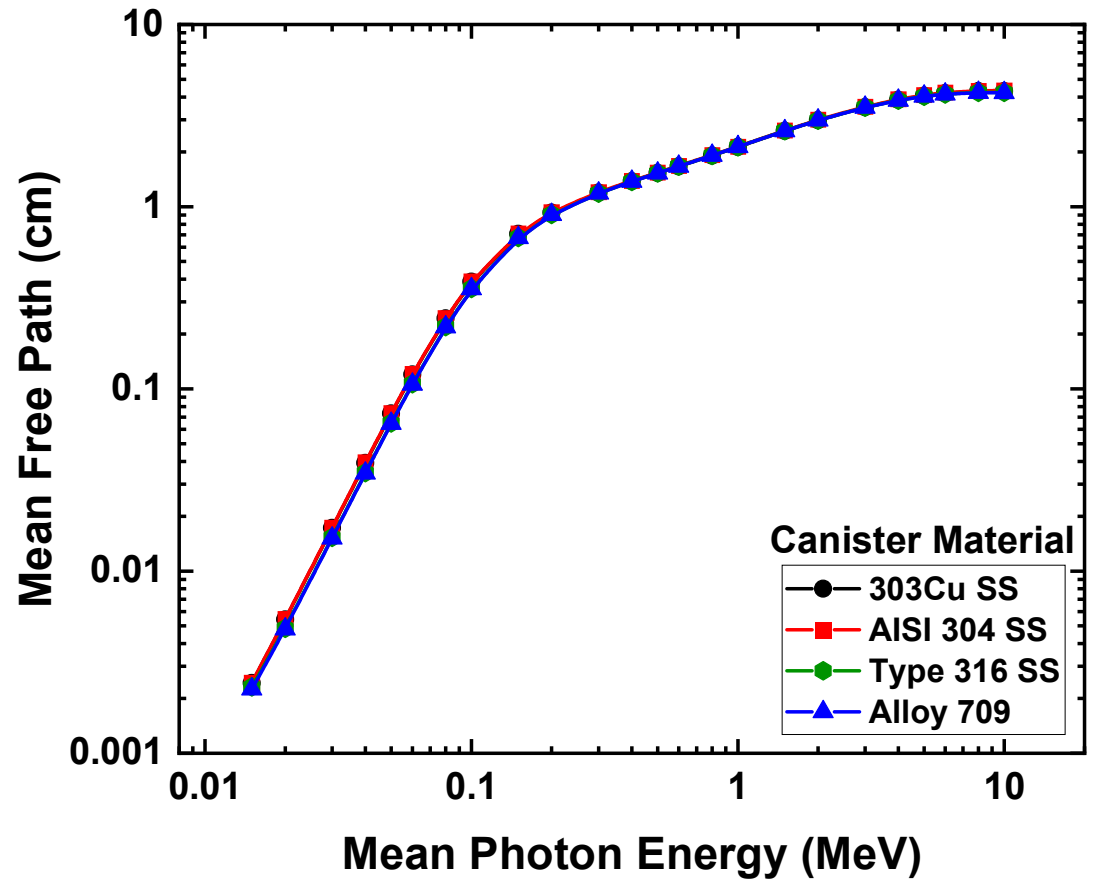

Figure 7: Mean free path (MFP) as function of photon energy for the selected stainless steels.

\subsection{Exposure Buildup Factor}

At fixed penetration depth of 20 MFP, Figure. 8 depicts the variation of the exposure buildup factor as function of photon 
energy for the investigated stainless steels. The exposure buildup factor increases with increasing the incident photon energy in which it reaches its maximum value at $0.5 \mathrm{MeV}$ for all stainless steels then starts to decrease with further increase in the photon energy. The increase in the exposure buildup factor at lower energies results from the dominant process of photoelectric effect while at higher energies, the decrease in the exposure buildup factor results from the dominant process of pair production. At intermediate energies, the dominant process is Compton scattering where the probability of photon escape is high due to scattering over absorption in which it causes a degradation in the photon energy and thus leads to increasing the value of the exposure buildup factor [11,13]. Furthermore, Alloy 709 is shown to exhibit lower values of exposure buildup factor at photon energies ranging from $0.02 \mathrm{MeV}$ to $2.0 \mathrm{MeV}$ while at higher energies, $303 \mathrm{Cu}$ SS and AISI 304 SS exhibit the minimum exposure buildup values.

On the other hand, Figure. 9 shows the variation of the exposure buildup factor as function of penetration depth (MFP) at fixed incident photon energy of $10 \mathrm{MeV}$ for the investigated stainless steels. As shown, the exposure buildup factor increases with increasing penetration depth for all stainless steels. At penetration depth less than 10 MFP, there is no significant difference in the exposure buildup factor between all stainless steels while there is a considerable difference at penetration depths higher than 10 MFP.

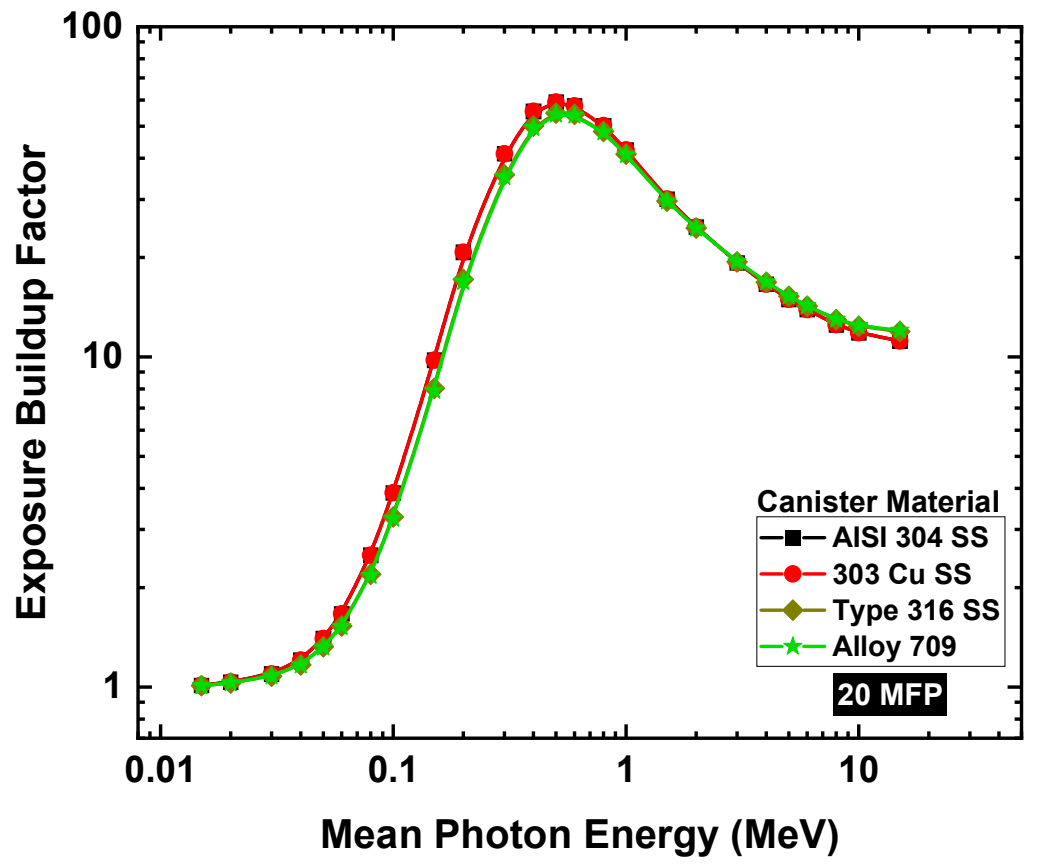

Figure 8: Buildup factor as function of photon energy at 20 MFP for the selected stainless steels. 


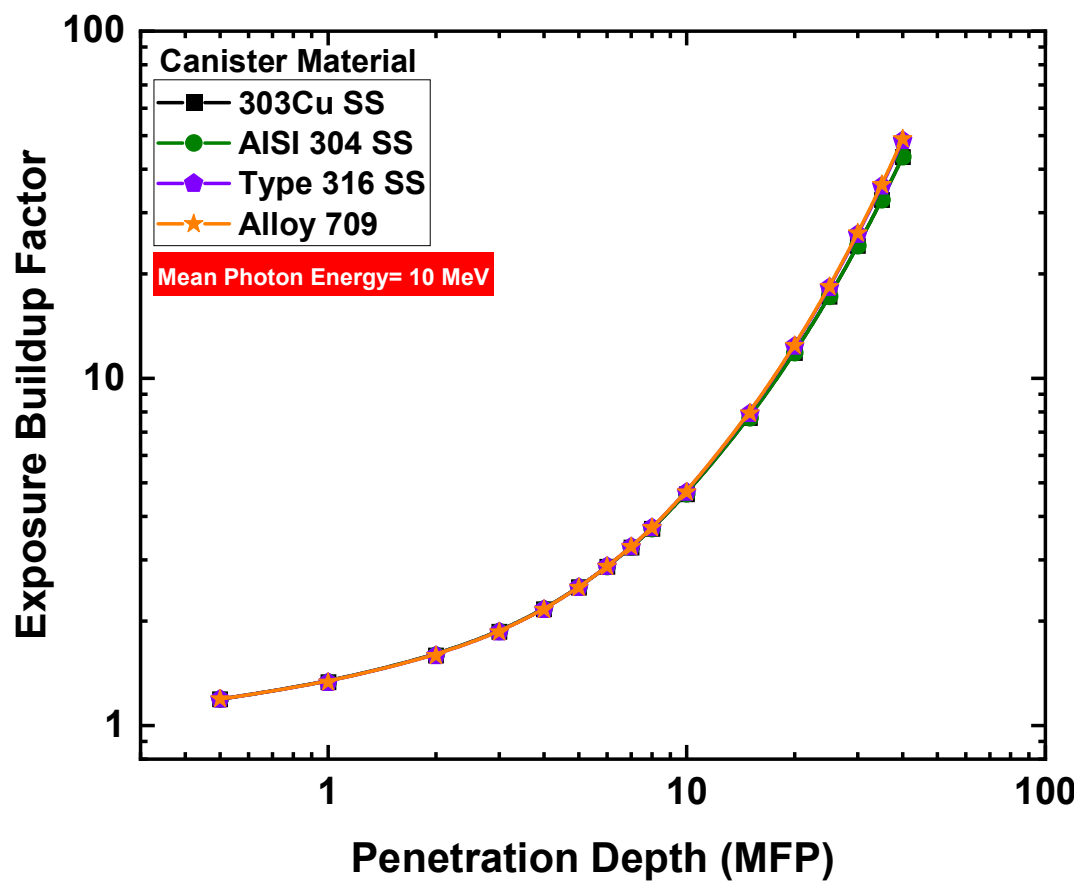

Figure 9: Buildup factor as function of penetration depth (MFP) at $10 \mathrm{MeV}$ photon energy for the selected stainless steels.

\section{CONCLUSIONS}

The advanced austenitic stainless steel Alloy 709 (Fe-25Ni-20Cr) is developed as structural material for boiler tubing and high-temperature applications such as ultra-supercritical (USC) power plants and Sodium-cooled Fast Reactors (SFRs). The shielding properties of Alloy 709 are computationally investigated as a candidate inner canister material in multilayered spent fuel dry cask and compared to other stainless steels. The modeled cask consists of three layers: the inner canister made of $0.27 \mathrm{ft}$ thick Alloy 709 advanced austenitic stainless steel, $0.2 \mathrm{ft}$ thick intermediate shielding coating of specialty high-density glass denoted as 'Glass 6 ' and $1.8 \mathrm{ft}$ thick outer shielding layer of specialty concrete overpack denoted as 'Concrete 6'. The source of the spent fuel used in the calculations is $8.727 \mathrm{ft}$ radius and $20 \mathrm{ft}$ height of the H. B. Robinson spent fuel that was depleted according to $72 \mathrm{GWd}$ /MTU burnup followed by an 8-year decay. It is concluded that Alloy 709 has shown higher attenuation among other steels at photon energies varying from $0.015 \mathrm{MeV}$ to $0.2 \mathrm{MeV}$, which can be ascribed to the high weight fraction of $\mathrm{Cr}(19.93 \%)$ and $\mathrm{Ni}(24.98 \%)$ and the additives of Titanium (Ti), Niobium $(\mathrm{Nb})$ and Boron $(\mathrm{B})$ that play a role in enhancing the attenuation behavior of the alloy against gamma-rays compared to other stainless steels. Alloy 709 has better reduction in exposure rate at photon energies ranging from $0.5 \mathrm{MeV}$ to $4.0 \mathrm{MeV}$ due to its high attenuation coefficients. At fixed penetration depth of $20 \mathrm{MFP}$, Alloy 709 is shown to exhibit lower values of exposure buildup factor at photon energies ranging from $0.02 \mathrm{MeV}$ to $2.0 \mathrm{MeV}$. Also exhibits lower HVL values at photon energies ranging from $0.06 \mathrm{MeV}$ to $0.5 \mathrm{MeV}$ and from $3.0 \mathrm{MeV}$ to $15 \mathrm{MeV}$, which explains its better attenuation among other steels and thus its enhanced shielding properties due to lesser volume requirements to attenuate the same amount of radiation. At photon energies ranging from $0.015 \mathrm{MeV}$ to $0.5 \mathrm{MeV}$ and from $3.0 \mathrm{MeV}$ to $15 \mathrm{MeV}$, Alloy 709 exhibits lower mean free path among other steels and thus, the best shielding effectiveness as canister material in dry storage casks of spent fuel. 


\section{ACKNOWLEDGEMENT}

Work supported by the Russell Family Foundation Grant for research on High Level Waste Packages and Dry Casks.

\section{REFERENCES}

1. Baskar R, et al. Cancer and radiation therapy: current advances and future directions. Int J Med Sci. 2012;9(3):193-199.

2. Al-Buriahi, M.S., et al. Investigation of barium borate glasses for radiation shielding applications. Appl. Phys. A 126, 68 (2020).

3. Al-Buriahi, M.S., Tonguc, B.T. Study on gamma-ray buildup factors of bismuth borate glasses. Appl. Phys. A 125, 482 (2019).

4. Sayyed, M.I., et al. Experimental studies on the gamma photons-shielding competence of $\mathrm{TeO}_{2}-\mathrm{PbO}-\mathrm{BaO}-\mathrm{Na}_{2} \mathrm{O}-$ $\mathrm{B}_{2} \mathrm{O}_{3}$ glasses. Appl. Phys. A 126, 4 (2020).

5. A.S. Abouhaswa, et al. Synthesis, structure, optical and gamma radiation shielding properties of $\mathrm{B}_{2} \mathrm{O}_{3}-\mathrm{PbO}_{2}-\mathrm{Bi}_{2} \mathrm{O}_{3}$ glasses, Composites Part B: Engineering, Volume 172, 2019, Pages 218-225.

6. RAHMAN, SHAIK ABDUR, GS GURU DATTATREYA, and N. KRISHNARJUNA RAO. "EXPERIMENTAL INVESTIGATION ON DIESEL ENGINE FUELLED WITH BLENDS OF COCONUT AND NEEM OIL." International Journal of Mechanical and Production Engineering Research and Development (IJMPERD) 9.5, Oct 2019, 391-402

7. M.I. Sayyed, et al. Borate multicomponent of bismuth rich glasses for gamma radiation shielding application, Radiation Physics and Chemistry, Volume 161, 2019, Pages 77-82.

8. Gaikwad, D.K., et al. (2018). Comparative study of gamma ray shielding competence of $\mathrm{WO}_{3}-\mathrm{TeO}_{2}-\mathrm{PbO}$ glass system to different glasses and concretes. Mater. Chem. Phys. 213, 508-517.

9. O. Agar et al., An investigation on shielding properties of $\mathrm{BaO}, \mathrm{MoO}_{3}$ and $\mathrm{P}_{2} \mathrm{O}_{5}$ based glasses using $M C N P X$ code, Results in Physics, Volume 12, 2019, Pages 629-634.

10. MESHRAM, DIWESH, et al. "Algae Fuel Technology-Concept of Revolutionary Future." Research and Development (IJAERD) 3.3 (2013): 15-28.

11. Kaky, K.M. et al., (2019). Structural, optical and radiation shielding properties of zinc boro-tellurite alumina glasses. Appl. Phys. Mater. Sci.

12. El-Sayed A. Waly et al., Impact of specialty glass and concrete on gamma shielding in multi-layered PWR dry casks, Progress in Nuclear Energy, Volume 94, 2017, Pages 64-70.

13. El-Sayed A. Waly, Mohamed A. Bourham, Comparative study of different concrete composition as gamma-ray shielding materials, Annals of Nuclear Energy, Volume 85, 2015, Pages 306-310.

14. El-Sayed A. Waly, et al. Shielding properties of glasses with different heavy elements additives for radiation shielding in the energy range 15-300 keV, Radiation Physics and Chemistry, Volume 150, 2018, Pages 120-124.

15. El-Sayed A. Waly, et al. Gamma-ray mass attenuation coefficient and half value layer factor of some oxide glass shielding materials, Annals of Nuclear Energy, Volume 96, 2016, Pages 26-30.

16. Kaur, Updesh, et al. Comparative studies of different concretes on the basis of some photon interaction parameters. United Kingdom: N. p., 2012.

17. Singh, T., et al. (2009). Chemical composition dependence of exposure buildup factors for some polymers. Ann. Nucl. Energy $36,114-120$. 
18. M.S. Al-Buriahi, et al. Structure, optical, gamma-ray and neutron shielding properties of $\mathrm{NiO}$ doped $\mathrm{B}_{2} \mathrm{O}_{3}-\mathrm{BaCO}_{3}-\mathrm{Li}_{2} \mathrm{O}_{3}$ glass systems. Ceramics Int. 46, 1711-1721 (2020).

19. Natrayan, L., Maharshi Singh, and M. Senthil Kumar. "An experimental investigation on mechanical behaviour of SiCp reinforced Al 6061 MMC using squeeze casting process." Inter J Mech Prod Engi Res Develop 7.6 (2017): 663-668.

20. Herrera, A., et al. (2016). Spectroscopic properties of $\mathrm{B}_{2} \mathrm{O}_{3}-\mathrm{PbO}-\mathrm{Bi}_{2} \mathrm{O}_{3}-\mathrm{GeO}_{2}$ glass doped with Sm3+ and gold nanoparticles. Opt. Mater. 52, 230-236.

21. Lakshminarayana, G., et al. (2018). Optical absorption and gamma-radiation-shielding parameter studies of Tm3+-doped multicomponent borosilicate glasses. Appl. Phys. Mater. Sci. Process 124, 0.

22. KUMAR, SANJAY, SP TEWARI, and JK SINGH. "MICROSTRUCTURAL EVOLUTION AND MECHANICAL PROPERTIES OF MIG WELDED AA6061 ALUMINUM ALLOY." International Journal of Mechanical and Production Engineering Research and Development (IJMPERD) 10.1, Feb 2020, 709-718

23. Zeinab Y. Alsmadi. High Temperature Creep-Fatigue Behavior of Alloy 709 Austenitic Stainless Steel in Sodium-Cooled Fast Reactors. Ph.D. thesis, North Carolina State University (2020).

24. T. Shrestha. Creep Deformation, Rupture Analysis, Heat Treatment and Residual Stress Measurement of Monolithic and Welded Grade 91 Steel for Power Plant. University of Idaho (2013).

25. T. Sourmail and H. K. D. H. Bhadeshia. Microstructural evolution in two variants of NF709 at 1023 and 1073 K. Metall. Mater. Trans. A, vol. 36, no. 1, pp. 23-34 (2005).

26. Zeinab Y. Alsmadi, et al. Effect of hold time on high temperature creep-fatigue behavior of Fe-25Ni-20Cr (wt.\%) austenitic stainless steel (Alloy 709). Materials Science and Engineering: A, vol. 771 (2020).

27. M. Mayuzumi, J. Tani, T. Arai. Chloride induced stress corrosion cracking of candidate canister materials for dry storage of spent fuel, Nuclear Engineering and Design, Volume 238, Issue 5, 2008, Pages 1227-1232.

28. Jun-ichi Tani, Masami Mayuzumi, Nobuyoshi Hara. Stress corrosion cracking of stainless-steel canister for concrete cask storage of spent fuel, Journal of Nuclear Materials, Volume 379, Issues 1-3, 2008, Pages 42-47.

29. Gonzalez, B.M., et al. (2003). The influence of copper addition on the formability of AISI 304 stainless steel. Mat. Sci. Eng. A343, 51-56.

30. ThoughtCo. Website, https://www.thoughtco.com/type-316-and-316l-stainless-steel-2340262.

31. W. Corwin. Advanced Structural Materials (RC-3) Nuclear Energy University Programs. (NEUP) Fiscal Year (FY) 2015 Annual Planning Webinar (2014).

32. “Available Methods for Functional Monitoring of Dry Cask Storage Systems". U.S. Nuclear Regulatory Commission Contract NRC-HQ-12-C-02-0089. November 2014.

33. Devireddy, K. R. I. S. H. N. A. J. A., et al. "Analysis of the influence of friction stir processing on gas tungsten arc welding of 2024 aluminum alloy weld zone." Int. J. Mech. Prod. Eng. Res. Dev 8.1 (2018): 243-252.

34. "High-temperature Characteristics of Stainless Steels". A Designers Handbook Series No. 9004 Produced by American Iron and Steel Institute.

35. Swathi Upadhayay. Tensile Properties of Advanced Austenitic Stainless Steel, Alloy 709, using In-Situ SEM Heating and Loading. Master of Science thesis, North Carolina State University (2017).

36. "Characterization of Creep-Fatigue Crack Growth In Alloy 709 And Prediction Of Service Lives In Nuclear Reactor 
Components". NEUP DOE Award Number: DE-NE0008443 Project 15-8623 Final Report. April 30 2019.

37. NF709. Nippon Steel \& Sumitomo Metal, August 4 ${ }^{\text {th }}$, 2019. http://www.tubular.nipponsteel.com/product-services/specialtytube/product/nf709.

38. UNS 303Cu, Tool \& Die Steels. https://www.aesteiron.com/1-4570-303cu-material-composition.pdf.

39. Kaundal, R.S., et al. (2010). Investigation of structural properties of lead strontium borate glasses for gamma-ray shielding applications. J. Phys. Chem. Solids 71, 1191-1195.

40. Naegeli, R.E., (2004). Calculation of Radionuclides in PWR Spent Fuel Samples for SFR Experiment Planning. Sandia National Laboratories.

41. MicroShield, Grove Software, http://radiationsoftware.com/microshield/.

42. U.S. Nuclear Regulatory Commission, (2002). Radioactive Waste: Production, Storage Disposal. NUREG/BR-0216, Rev. 2.

43. U.S. Nuclear Regulatory Commission, (2015). Typical dry cask storage system. Retrieved from 〈http://www.nrc.gov/waste/spent-fuel-storage/diagramtypical-dry-casksystem.html). 

